УДК 534.1

\title{
RESONANT OSCILLATIONS OF A ROTOR ON AXIALLY PRELOADED BALL BEARINGS UNDER THE JOINT ACTION OF UNBALANCE AND VIBRATION OF SUPPORTS
}

\author{
S. Filipkovskyi, Assoc. Prof., Ph. D (Eng.), R. Makovyey, Asst. Prof., \\ Kharkov National Automobile and Highway University
}

\begin{abstract}
The model of nonlinear vibrations of the rotor supported by axial preload angular ballbearings was developed. The frequency response of the system is obtained by the continuation method at joint action of unbalance and vibration of supports. Analysis showed that vibrations occurred not only at fundamental resonant frequencies but also at frequencies less than the resonant ones in integer times. The character of periodical decisions is investigated.
\end{abstract}

Key words: rotor, angular ball bearing, nonlinear vibrations, resonance.

\section{РЕЗОНАНСНЫЕ КОЛЕБАНИЯ РОТОРА НА ШАРИКОПОДШИПНИКАХ С ОСЕВЫМ НАТЯГОМ ПРИ СОВМЕСТНОМ ДЕЙСТВИИ ДИСБАЛАНСА И ВИБРАЦИИ ОПОР}

\author{
С.В. Филипковский, доц., к.т.Н., Р.Г. Маковей, ст. преп., \\ Харьковский национальный автомобильно-дорожный университет
}

\begin{abstract}
Аннотация. Получена модель нелинейных колебаний ротора на радиально-упорных шарикоподшипниках с предварительным осевым натягом. Методом продолжения по параметру получена амплитудно-частотная характеристика системы при совместном действии дисбаланса и вибрации опор. Анализ показал, что колебания возникают не только на основных резонансных частотах, но и на частотах меньше резонансных в целое число раз.
\end{abstract}

Ключевые слова: ротор, радиально-упорный шарикоподшипник, нелинейные колебания, резонанс.

\section{РЕЗОНАНСНІ КОЛИВАННЯ РОТОРА НА ШАРИКОПІДШИПНИКАХ З ОСЬОВИМ НАТЯГОМ ПРИ СПІЛЬНІЙ ДІЇ ДИСБАЛАНСУ І ВІБРАЦІЇ ОПОР}

С.В. Філіпковський, доц., к.т.н., Р.Г. Маковєй, ст. викл., Харківський національний автомобільно-дорожній університет

Анотація. Отримано модель нелінійних коливань ротора на радіально-упорних шарикопідшипниках з попереднім осьовим натягом. Методом продовження по параметру отримано амплітудно-частотну характеристику системи при спільній дії дисбалансу і вібрації опор. Аналіз показав, щуо коливання виникають не тільки на основних резонансних частотах, але $i$ на частотах менше резонансних в ціле число разів.

Ключові слова: ротор, радіально-упорний шарикопідщипник, нелінійні коливання, резонанс.

\section{Introduction}

Many devices of special vehicles, for example gyroscopic instruments, fans, centrifugal compressors operate under conditions of vibration, which propagates through the machine structure, even in the presence of vibration isolation. The rotors of these units must be protected from impacts that may occur as a result of opening and closing the clearances between the rolling balls 
and races of bearings under transverse rotor vibration. These rotors are mounted on angular contact ball bearings with axial preload.

\section{Analysis of publications}

The equations for determining the non-linear stiffness of preloaded bearings are derived in [1], however, for the carried out in this article research they are linearized. In the article [2], numerically and experimentally there were investigated the transverse vibrations of the preloaded angular-contact ball bearing rotor caused by an unbalance of the disc as well as show their dependence on the nonlinear contact forces. In article [3] there was studied the parametric instability of the shaft with ball bearings under the influence of a variable axial force.

In article [4] there were explored the free oscillations of the preloaded angular-contact ball bearing rotor as well as derived the backbone curves and nonlinear normal modes of oscillations at different angles between the line of action of the contact force and the bearing axis. In work [5], there was analyzed the nonlinear model of ball bearings, obtained on the basis of the formulas given in article [1] and defined the limits of applicability of this model.

\section{Purpose and problem statement}

Effect of supports vibration on forced oscillations of the rotor is not investigated so far. The solution to this problem is urgent, since in the nonlinear rotor systems there often occur superand sub-resonance oscillations. The aim of this study is to investigate the resonant oscillations occurring in the preloaded angular-contact ball bearing rotor caused by the simultaneous action of the unbalance and vibration of supports.

\section{Design model}

The rotor is a shaft with a disk fixed eccentrically relative to supports (Fig. 1). Designation and conditions of machines operation, in which they use axial preloaded ball bearings, are such that the co-relation of the length and diameter of the shaft determine the stiffness of the shaft in the order of magnitude more than the rigidity of bearings. Therefore, the shaft is considered to be a non-deformable body, the rotor center of mass is considered to be concentrated in the center of the disc, and the degrees of freedom are the spindles movement relative to the outer bearing rings.

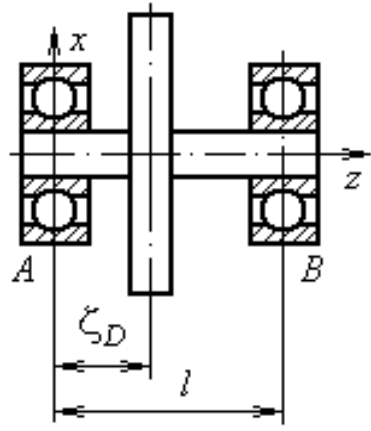

Fig. 1. Rotor design

The components of elastic bearing reactions along the coordinate axes were derived in work [1]. One can consider them to be the components of the vector function $\mathbf{K}(\mathbf{X})$, where $\mathbf{X}$ is the vector of generalized coordinates.

\section{Equations of rotor oscillations}

The length of the shaft will be denoted $l$; movement of the shaft center line in the directions of the coordinate axes $u_{x}, u_{y}$ are as follows:

$$
\begin{aligned}
& u_{x}(\zeta, t)=x_{1}(t) \frac{l-\zeta}{l}+x_{2}(t) \frac{\zeta}{l}, \\
& u_{y}(\zeta, t)=y_{1}(t) \frac{l-\zeta}{l}+y_{2}(t) \frac{\zeta}{l},
\end{aligned}
$$

where $\zeta$ is the coordinate of the shaft crosssection along the axis $z, x_{1}(t), x_{2}(t), y_{1}(t)$, $y_{2}(t)$ are generalized coordinates describing the radial movement of spindles; $t$ is a time. The inner rings of ball bearings produce both radial and axial oscillations relative to the outer rings. Let's note that the movement is insufficient compared with the length of the shaft. Then, the longitudinal oscillations of the rotor along the coordinate axis $z$ can be described by a generalized coordinate $u_{z}=z(t)$.

To generate the equations of motion, one can use the Lagrange equations. Under our assumptions, the expression of the kinetic energy of the shaft $\mathrm{T}_{B}$ as a function of generalized coordinates will be as follows

$$
\begin{aligned}
& \mathrm{T}_{B}=\frac{\rho I}{2 l}\left(\dot{y}_{1}-\dot{y}_{2}\right)^{2}+\frac{\rho I}{2 l}\left(\dot{x}_{2}-\dot{x}_{1}\right)^{2}+\rho I l \Omega^{2}- \\
& -\frac{2 \rho I \Omega}{l}\left(\dot{x}_{2}-\dot{x}_{1}\right)\left(y_{1}-y_{2}\right)+\frac{\rho S l}{6} \times \\
& \times\left(\dot{x}_{1}^{2}+\dot{x}_{1} \dot{x}_{2}+\dot{x}_{2}^{2}+\dot{y}_{1}^{2}+\dot{y}_{1} \dot{y}_{2}+\dot{y}_{2}^{2}\right)+\frac{\rho S l}{2} \dot{z}^{2},
\end{aligned}
$$


where $\rho$ is density of the shaft material, $I$ and $S$ are the second moment of area and the area of the shaft, respectively; $\Omega$ is an angular speed of the rotor. The kinetic energy of the disk $T_{D}$ as a function of generalized coordinates will be

$$
\begin{aligned}
& \mathrm{T}_{D}=\frac{I_{1}}{2}\left(\frac{\dot{y}_{1}-\dot{y}_{2}}{l}\right)^{2}+\frac{I_{1}}{2}\left(\frac{\dot{x}_{2}-\dot{x}_{1}}{l}\right)^{2}+ \\
& +\frac{I_{0}}{2} \Omega^{2}+I_{0} \Omega \frac{\left(\dot{y}_{1}-\dot{y}_{2}\right)\left(x_{2}-x_{1}\right)}{l^{2}}+ \\
& +\frac{m_{0}}{2}\left[\dot{x}_{1}\left(1-\frac{\zeta_{D}}{l}\right)+\dot{x}_{2} \frac{\zeta_{D}}{l}\right]^{2}+ \\
& +\frac{m_{0}}{2}\left[\dot{y}_{1}\left(1-\frac{\zeta_{D}}{l}\right)+\dot{y}_{2} \frac{\zeta_{D}}{l}\right]^{2}+\frac{m_{0}}{2} \dot{z}^{2},
\end{aligned}
$$

where $I_{1}$ and $I_{0}$ are the diametrical and polar moments of inertia of a disk, respectively, $m_{0}$ is the mass of the disk, $\zeta_{D}$ is the disk coordinate along the axis $z$.

From the assumption that the shaft is nondeformable, it follows that the potential energy of system deformation is represented only by the energy of deformation of bearings $\Pi=\Pi_{\Pi}\left(x_{1}, y_{1}, x_{2}, y_{2}, z\right)$. Derivatives of the potential energy on generalized coordinates are components of the vector function $\mathbf{K}(\mathbf{X})$.

Damping is due to bearings lubrication, usually it is determined on the basis of experiments and described by the model of viscous friction [6, 7]. In this case, the Rayleigh dissipation function $\Phi$ has the form

$$
\Phi=\frac{C}{2}\left(\dot{x}_{1}^{2}+\dot{y}_{1}^{2}+\dot{x}_{2}^{2}+\dot{y}_{2}^{2}+\dot{z}^{2}\right),
$$

where $C$ is the damping factor.

Using expressions (1), (2), (3) and (4), one can obtain the equation of oscillations in the matrix form

$$
\mathbf{M} \cdot \ddot{\mathbf{X}}+\mathbf{G} \cdot \dot{\mathbf{X}}+\mathbf{C} \cdot \dot{\mathbf{X}}+\mathbf{K}(\mathbf{X})=\mathbf{Q}(t),
$$

where $\mathbf{M}$ is the mass matrix, $\mathbf{G}$ is the gyroscopic matrix, $\mathbf{C}$ is the damping matrix, $\mathbf{Q}(t)$ is the right-hand part vector.

Oscillations are excited by the combined effect of the disk unbalance forces and the vibration of supports, therefore

$$
\mathbf{Q}(t)=\mathbf{Q}_{D}(\Omega, t)+\mathbf{Q}_{\Pi}(\omega, t),
$$

where $\mathbf{Q}_{D}(\Omega, t)$ is the vector of forces due to unbalance of the disk, $\mathbf{Q}_{\Pi}(\omega, t)$ - the vector of kinematic excitation of oscillations, $\omega$ is the angular frequency of vibration of supports. The first vector is obtained by differentiating (3). Its components have the following form

$$
\begin{gathered}
Q_{D}(\Omega, t)_{1}=m_{0} a \Omega^{2}\left(1-\frac{\zeta_{D}}{l}\right) \cos \Omega t, \\
Q_{D}(\Omega, t)_{2}=m_{0} a \Omega^{2}\left(1-\frac{\zeta_{D}}{l}\right) \sin \Omega t \\
Q_{D}(\Omega, t)_{3}=m_{0} a \Omega^{2} \frac{\zeta_{D}}{l} \cos \Omega t \\
Q_{D}(\Omega, t)_{4}=m_{0} a \Omega^{2} \frac{\zeta_{D}}{l} \sin \Omega t \\
Q_{D}(\Omega, t)_{5}=0
\end{gathered}
$$

The second vector in (6) should be written as follows [8]

$$
\mathbf{Q}_{\Pi}(\omega, t)=\mathbf{M} \cdot \mathbf{A}_{\Pi}(\omega, t),
$$

where $\mathbf{M}$ is the mass matrix, $\mathbf{A}_{\Pi}(\omega, t)$ is the vector of vibration acceleration of supports,

$$
\begin{aligned}
& \mathbf{A}_{\Pi}(\omega t)= \\
& =\left[\begin{array}{lllll}
A_{\Pi x 1} & A_{\Pi y 1} & A_{\Pi x 2} & A_{\Pi y 2} & A_{\Pi z}
\end{array}\right]^{\mathrm{T}} \sin \omega t,
\end{aligned}
$$

where $A_{\Pi x 1}, \ldots, A_{\Pi z}$ are the vibration acceleration amplitude.

\section{Numerical analysis of forced vibrations}

To study the periodic solutions of the equation (5), we'll build a frequency response of peak-topeak displacements caused by frequency $\omega$. Frequency $\Omega$ is considered to be fixed. Let's define the dimensionless parameters as follows: $x_{A}=x_{1} / z_{0}, \quad y_{A}=y_{1} / z_{0}, \quad x_{B}=x_{2} / z_{0}$, $y_{B}=y_{2} / z_{0}, z_{A}=z / z_{0}, \bar{\omega}=\omega / \omega_{1}, \bar{\Omega}=\Omega / \omega_{1}$, $\tau=t \cdot \omega_{1}$, where $z_{0}$ is an axial displacements of the inner ring of the bearing with respect to the outer ring due to the action of the preload force, $\omega_{1}$ is the fundamental resonant frequency of the linearized system. In this work, analysis of the solutions of equation (5) is formed, using the continuation method that was proposed in work [9] and improved in work [10] in the study of nonlinear rotor vibrations caused by unbalance. 
Oscillations of the non-deformable rotor with one disk $l=0,5 \mathrm{~m}, \zeta_{D}=0,125 \mathrm{~m}$, the shaft diameter $d=0,025 \mathrm{~m}, \quad m_{0}=10 \mathrm{~kg}, \quad I_{1}=0,1 \mathrm{~kg} \cdot \mathrm{m}^{2}$, $I_{0}=0,2 \mathrm{~kg} \cdot \mathrm{m}^{2}$ that rotates on angular contact bearings of average series as per GOST Standard 831-75 are considered. The bearing parameters are as follows: the radius of the outer race $R_{2}=27,5167 \mathrm{~mm} ; \alpha=15^{\circ}$; the radius of the inner race $R_{1}=16,000 \mathrm{~mm}$; the radius of the cross section of races $R_{K}=5,930 \mathrm{~mm}$; the ball diameter $d_{B}=11,510 \mathrm{~mm}$; the number of balls $N_{B}=7$; the modulus of elasticity $E=2,1 \cdot 10^{11} \mathrm{~Pa}$; Poisson ratio $\mu=0,3$.

At joint action of the unbalance and vibration of supports the basic resonant oscillations occur in form when the shaft spindles are located at one side of the bearing axis and move in a circle in the shaft rotation direction. The frequency of these oscillations corresponds to the third frequency of free oscillations and is further defined by $\bar{\omega}_{3}$. Besides this resonance there appear resonances of other forms of rotor oscillations as well as super-resonance oscillations. Fig. 2 shows the frequency response of the coordinate $y_{B}$ due to parameter $\bar{\omega}$.

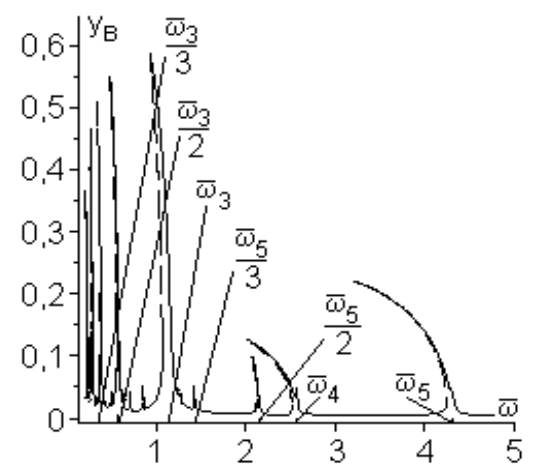

Fig. 2. Frequency response $y_{B}$ due to $\bar{\omega}$

The resonance peaks $\bar{\omega}_{5}, \bar{\omega}_{5} / 2$ and $\bar{\omega}_{5} / 3$ correspond to the modes when the shaft spindles are located on opposite sides of the axis of symmetry of bearings and during oscillations move towards the rotor rotation. Super-resonance frequencies $\bar{\omega}_{5} / 2$ and $\bar{\omega}_{5} / 3$ refer to resonance frequency $\bar{\omega}_{5}$ as integers $-1 / 2$ and $1 / 3$.

Resonance $\bar{\omega}_{4}$ corresponds to the form when the shaft spindles are located on opposite sides of the axis of symmetry of bearings and during oscillations move oppositely the shaft rotation. The frequencies $\bar{\omega}_{4}$ and $\bar{\omega}_{5}$ represent the fourth and fifth frequency of free oscillations. In Fig. 2 resonances with lower frequencies corresponding to these modes are noticeable. Their peak-to- peak displacements are small and the frequencies are also treated as integers.

The resonant peak $\bar{\omega}_{3}$ has the highest magnitude. In the region of low frequencies in Fig. 2 there can be seen super-resonances $\bar{\omega}_{3} / 2$ and $\bar{\omega}_{3} / 3$ as well as not marked in the figure $\bar{\omega}_{3} / 4$ and $\bar{\omega}_{3} / 5$, which correspond to the modes when the shaft spindles are located at one side of the axis of symmetry of bearings and during oscillations move towards the shaft rotation. Their frequencies refer to the frequency of the fundamental resonance as $1 / 2,1 / 3,1 / 4,1 / 5$.

\section{Analysis of resonant oscillation modes}

The orbit $\mathrm{s}$ of the centers of shaft spindles on the main resonances of all modes are close to a circles as shown in Fig. 3 for the mode corresponding to $\bar{\omega}_{3}(\bar{\omega}=0,9858)$.

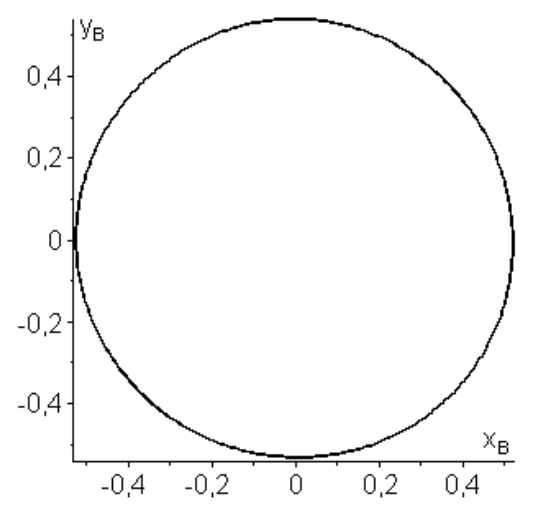

Fig. 3. The orbit of the spindle $B, \bar{\omega}=0,9858$

For super-resonance frequency during each cycle of oscillation the shaft spindle describes as many loops close to the circumference as many times the frequency is lower than the fundamental frequency for this mode, as it is shown in Fig. 4 for $\bar{\omega}_{3} / 2$ and in Fig. 5 for $\bar{\omega}_{3} / 3$.

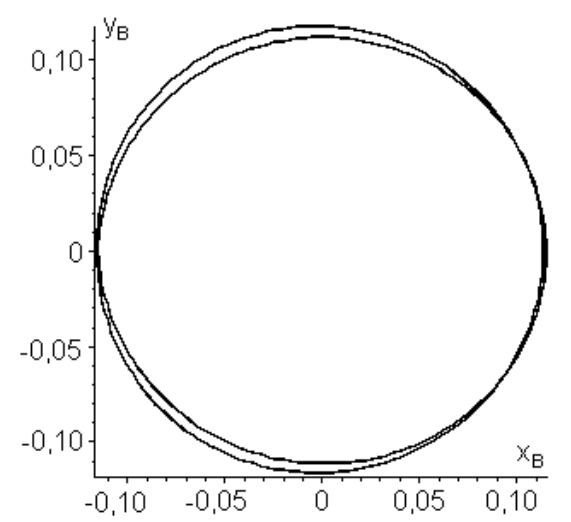

Fig. 4. The orbit of the spindle $B, \bar{\omega}=0,5619$ 
Between the peaks with big peak-to-peak displacements in Fig. 2 there can be clearly seen the peaks with relatively small displacements and frequencies relating to the resonance frequency $\bar{\omega}_{4}$ and $\bar{\omega}_{5}$ as integers. As a result of the superposition of oscillations according to several modes, here the orbits of the centers of spindles are more complex, as it is shown in Fig. 6 for the frequency $\bar{\omega}=0,5098$.

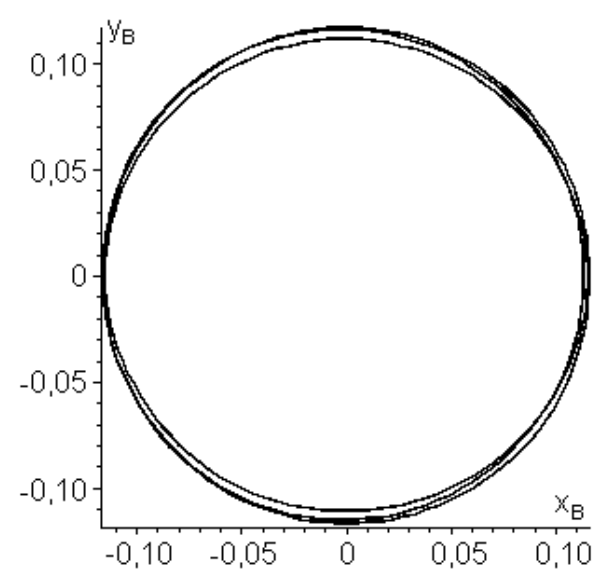

Fig. 5. The orbit of the spindle $B, \bar{\omega}=0,3746$

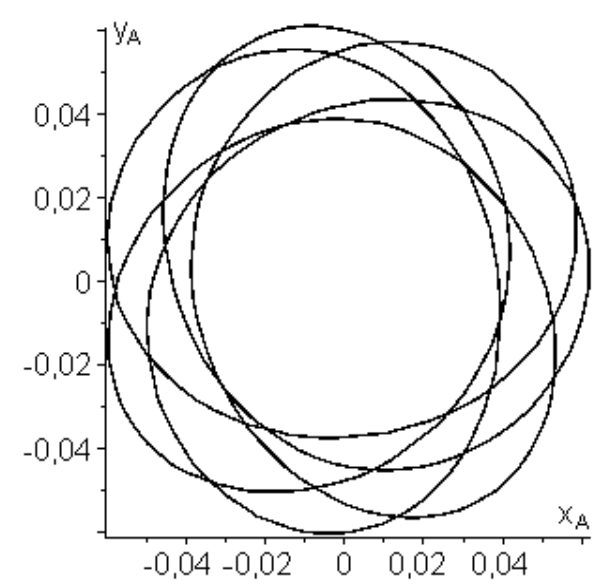

Fig. 6. The orbit of the spindle $A, \bar{\omega}=0,5098$

In this mode, there occurs the superposition of oscillations according to the modes of resonances $\bar{\omega}_{3}$ and $\bar{\omega}_{5}$.

\section{Conclusions}

Analysis of the nonlinear preloaded angularcontact ball bearings rotor dynamics has shown that at joint action of unbalance and vibration of supports there are excited several forms of rotor oscillations. All frequency responses are soft. In this case, besides the main resonance oscillations there occur super-resonance oscillations at frequencies lower than the resonant ones in an integer number of times.

Resonances corresponding to the modes, when the shaft spindles are located on one side of the symmetry axis of bearings have the largest amplitude, and the resonances corresponding to the modes, when the shaft spindles are located on opposite sides of the axis of symmetry of bearings and during oscillating move oppositely to the shaft rotation - the lowest amplitude.

This system behavior is explained by the complexity of disturbances due to the fact that the rotor rotation frequency is within the range of vibration frequencies of supports. The superposition of these disturbing vibrations leads to the fact that in the disturbing load there can be observed beats that cause super-resonant oscillations.

\section{References}

1. Новиков Л. 3. Определение собственных частот колебаний электродвигателя, связанных с нелинейной упругостью подшипников / Л. З. Новиков // Изв. АН СССР. Механика и машиностроение. 1961. - № 6. - C. 84-91.

2. Bai C. Subharmonic resonance of a symmetric ball bearing - rotor system / C. Bai, $\mathrm{H}$. Zhang, Q. Xu // International Journal of Non-Linear Mechanics. - 2013. - Vol. 50. P. 1-10.

3. Young T. H. Dynamic stability of rotorbearing systems subjected to random axial forces / T. H. Young, T. N. Shiau, Z. H. Kuo // Journal of Sound and Vibration. - 2007. Vol. 305(3). - P. 467-480.

4. Филипковский С.В. Свободные нелинейные колебания многодисковых роторов на шарикоподшипниках / С.В. Филипковский, К.В. Аврамов // Проблемы прочности. - 2013. - № 3. - С. 86-96.

5. Филипковский С. В. Модель радиальноупорного шарикоподшипника для анализа нелинейных вибраций ротора / С. В. Филипковский // Автомобильный транспорт: сб. науч. тр. - 2015. - Вып. 37. - C. 135-142.

6. Бальмонт В.Б. О колебаниях момента сопротивления вращению шарикоподшипника / В.Б. Бальмонт, Б О. Дубовецкий, А.М. Авдеев, Г.В. Селезнёв // Машиноведение. - 1988. - № 3. - С. 73-81. 
7. Позняк Э.Л. Маятниковые колебания несимметричного жесткого ротора в подшипниках с зазорами / Э.Л. Позняк, Т.Н. Гладышева, В.Б. Ковалев // Проблемы машиностроения и надежности машин. - 1990. - № 4.- С. 33-40.

8. Тимошенко С. П. Колебания в инженерном деле / С. П. Тимошенко, Д. Х. Янг, У. Уивер. - М.: Машиностроение, 1985. $472 \mathrm{c}$.

9. Беломытцев А. С. Алгоритм решения нелинейной краевой задачи для обыкновенных дифференциальных уравнений в области многозначности / А. С. Беломытцев, В. Н. Карабан // Журнал вычислительной математики и математической физики. - 1986. - № 7. - С. 1099-1102.

10. Филипковский С. В. Нелинейные колебания ротора на радиально-упорных шарикоподшипниках / С. В. Филипковский, А. С. Беломытцев // Вестник ХНАДУ: сб. науч. тр. - 2014.- Вып. 64. - С. 66-73.

\section{References}

1. Novikov L. Z. Opredelenie sobstvennyh chastot kolebanij elektrodvigatelja, svjazannyh s nelinejnoj uprugost'ju podshipnikov [Determination of the natural frequencies of the motor oscillations associated with the nonlinear elasticity of bearings]. Izv. AN SSSR. Mehanika i mashinostroenie. 1961. no. 6. pp. 84-91.

2. Bai C., Zhang H., Xu Q. Subharmonic resonance of a symmetric ball bearing - rotor system. International Journal of NonLinear Mechanics, 2013. Vol. 50. pp. 1-10.

3. Young T. H., Shiau T. N., Kuo Z. H. Dynamic stability of rotor-bearing systems subjected to random axial forces. Journal of Sound and Vibration, 2007, Vol. 305(3), pp. 467-480.

4. Filipkovskij S.V., Avramov K.V. Svobodnye nelinejnye kolebanija mnogodiskovyh rotorov na sharikopodshipnikah [Nonlinear Free Vibrations of Multi-Disk Rotors on
Ball Bearings]. Problemy prochnosti, 2013, no. 3. pp. 86-96.

5. Filipkovskiy S.V. Model radialno-upornogo sharikopodshipnika dlya analiza nelineynyih vibratsiy rotora [The model of angular ball-bearing for analysis of nonlinear vibrations of rotor]. Avtomobilnyiy transport, 2015, Vol. 37. pp. 135-142.

6. Bal'mont V.B., Duboveckij B.O., Avdeev A.M., Seleznjov G.V. O kolebanijah momenta soprotivlenija vrashheniju sharikopodshipnika [About oscillations of the moment of resistance to rotation of the ball bearing]. Mashinovedenie, 1988, no. 3. pp. 73-81.

7. Poznjak E.L. Gladysheva T.N., Kovalev V.B. Majatnikovye kolebanija nesimmetrichnogo zhestkogo rotora $v$ podshipnikah s zazorami [Pendulum oscillations of asymmetric rigid rotor in bearings with clearances]. Problemy mashinostroenija $i$ nadezhnosti mashin, 1990, no. 4. pp. 33-40.

8. Timoshenko S.P., Jang D. H., Uiver U. Kolebanija $v$ inzhenernom dele [Vibration Problems in Engineering]. Moskow, Mashinostroenie Publ., 1985. 472 p.

9. Belomytcev A.S., Karaban V.N. Algoritm reshenija nelinejnoj kraevoj zadachi dlja obyknovennyh differencial'nyh uravnenij $v$ oblasti mnogoznachnosti [An algorithm for solving nonlinear boundary value problems for ordinary differential equations in the ambiguity area]. Zhurnal vychislitel'noj matematiki i matematicheskoj fiziki. 1986. no. 7. pp. 1099-1102.

10. Filipkovskij S.V., Belomytcev A.S. Nelinejnye kolebanija rotora na radial'noupornyh sharikopodshipnikah [Nonlinear vibration of a rotor on the angular contact ball bearings]. Vestnik Harkovskogo nacionalnogo avtomobil'no-dorozhnogo un-ta. 2014. Vol. 64. pp. 66-73.

Рецензент: М. А. Подригало, профессор, д.т.н., ХНАДУ . 